Article

\title{
Evaluating Morphological Growth, Yield, and Postharvest Fruit Quality of Cucumber (Cucumis Sativus L.) Grafted on Cucurbitaceous Rootstocks
}

\author{
Waqas Aslam ${ }^{1}$, Rana Shahzad Noor ${ }^{2,3}{ }^{(D)}$, Fiaz Hussain ${ }^{3}$, Muhammad Ameen ${ }^{4}$, Saif Ullah ${ }^{1}$ and \\ Hong Chen ${ }^{1, *}$ \\ 1 College of Economics and Management, Northeast Forestry University, Harbin 150040, China; \\ aslam_waqas219@yahoo.com (W.A.); ranasaif2014@outlook.com (S.U.) \\ 2 Department of Agriculture, Biological, Environment and Energy Engineering, College of Engineering, \\ Northeast Agricultural University, Harbin 150030, China; engr.rsnoor@uaar.edu.pk \\ 3 Faculty of Agricultural Engineering and Technology, PMAS-Arid Agriculture University, Rawalpindi 46000, \\ Pakistan; engr.fiaz@uaar.edu.pk \\ 4 College of Engineering, Nanjing Agriculture University, Nanjing 210031, China; ameenkhan114@yahoo.com \\ * Correspondence: nefuchen@126.com; Tel.: +86-13936441436
}

Received: 20 January 2020; Accepted: 18 March 2020; Published: 2 April 2020

\begin{abstract}
Grafting is a substitute technique to boost tolerance against abiotic stresses, which also diminish root syndromes from soil-borne pathogens and increase crop production. This piloted study evaluates the tongue grafting technique and investigates the influence of grafting hybrid cucumber (Kalam $\mathrm{F}_{1}$ ) scion onto local cucurbitaceous and hybrid rootstocks on plant morphology, fruit yield, nutrients concentration in different plant organs, and postharvest fruit quality during three seasons of 2017 to 2019, consecutively. The research design was completely randomized (CRD), and the effects of grafted rootstocks were determined with comparison of percent plant survival, growth characteristics, fruit yield, and texture properties (during storage). The experimental results indicated that all rootstocks presented compatibility with hybrid cucumber (Kalam $\mathrm{F}_{1}$ ) scion and showed significant comparable performance with hybrid rootstock during all seasons in terms of vegetative growth, yield, and storage except pumpkin ( $68 \%$ during the 1 st, $74 \%$ during the 2 nd, and $71 \%$ during the 3 rd seasons). The plants with Bottle gourd (Lagrenaria siceraria) rootstock showed the highest survival rate as compared to all other cucurbitaceous and hybrid rootstocks during three seasons: $94 \%, 98 \%$, and $93 \%$, respectively. Similarly, the other factors such as plant height $(613,622$, and $615 \mathrm{~cm})$, fruit weight $(282,281$, and $277 \mathrm{~g})$, fruit shape index $(7.77,8.18$, and 8.25$)$, Total soluble solids (TSS) $(5.1 \%, 5.17 \%$, and $4.96 \%)$, fruit dry matter $(4.55 \%, 4.625$, and $4.57 \%)$, fruit yield $(4.37$, 4.9 , and $3.95 \mathrm{~kg} / \mathrm{plant})$, and disease resistance index $(<3)$ during three seasons were comparable with all other cucurbitaceous and hybrid rootstocks. The lower survival rate of pumpkin rootstock made a significant poor performance with lower growth, yield, nutrients, and storage than all other cucurbitaceous rootstocks. Ridge and Bitter gourds showed improved results for vegetative growth, yield, fruit characteristics, nutritional values, and storage performance than that of hybrid cucumber rootstock. The fruit textural and physical properties were found significantly better at $10^{\circ} \mathrm{C}$ than $25^{\circ} \mathrm{C}$ for 10 days of storage without quality deterioration, while no impact was perceived on physical properties of the fruit. According to economic analysis, the grafted cucumber production system showed higher net return and benefit-cost ratio (BCR) in comparison with the real rooted hybrid cucumber production system, which was assumed to be profitable practice.
\end{abstract}

Keywords: hybrid cucumber; tongue grafting; vegetative and fruit characteristics; plant nutrient concentration; storage performance; textural physical properties 


\section{Introduction}

Cucumber is the most economically popular and widely grown crop in Pakistan, with 60,611 tons per year production rate [1]. During the past few years, hybrid cucumber was intensively grown in different areas of the country, but the critical problem is low yield due to unfavorable soil properties, soil-borne diseases, and successive cropping method. Crop rotation is the most effective way to remediate such issues by avoiding cucumber cultivation in the same field for at least five years. Vegetable farming adversely affects cucumber production, especially in a greenhouse [2]. The reduction in soil-borne pathogenic diseases is a challenging task for sustainable agriculture [3], while the adapting trend of monoculture rather than polyculture system is susceptible and endangers agriculture sustainability and diversity [4]. According to an estimate, around $11 \%$ annual average yield loss was suffered due to unavailable proper resistant for the nematodes [5].

Grafting is an effective integrated pest-management strategy to manage soil-borne pathogens and other pests of cucurbitaceous crops. Grafting of susceptible cucumber varieties onto resistant rootstock can significantly enhance plant growth, fruit yield, and quality [2]. Grafting is an applied technique for sustainable agricultural practices and the protection of crops from soil-borne pathogens, soil $\mathrm{pH}$, nematodes, and salinity [6]. Soil-borne diseases can be controlled by grafting techniques effectively, that can improve and develop mineral and nutrient intake within plants [7]. Previous studies reported the effects of rootstock on plant nutrient uptake and translocation and on nutrient absorption of different plant tissues. The grafting scion on appropriate rootstocks can medicate these complications and issues [8].

Several studies have demonstrated that grafting can improve plant growth, yield, vigor, earliness, and abiotic stress tolerance [9]. Generally, all these scion characteristics depend on rootstock genotype, which can modify tolerance, resistance, or susceptibility to biotic and abiotic constraints [10]. Moradipour et al. pointed out the considerable effect of rootstock on yield and other developing topographies [11]. The giftedness is compacted by cucumber grafting on other rootstocks, but the collective yield increases meaningfully as linked to non-grafted cucumber [12]. There is an increase in fructose and sweetness content, which pointed out the consequence of rootstocks [13]. The grafted plants samples have different collar sizes (diameter) depending on rootstock [12]. Sakata et al. stated some factors for the best choice of rootstock like production area, scions, cultivars, and rootstock species [14], while Davis et al. suggested careful selection for rootstock/scions combination related to specific geographic and climatic condition to prevent soil-borne diseases, to improve quality, and to increase yield [15].

Grafting has contributed to sustainable agriculture by reducing the amount of agrochemicals used to disinfect the soil, as it has been used to confer tolerance to pests and diseases of the root system, to improve fruit quality, and to increase the absorption of nutrients and yields. Bloomless rootstocks alter several characteristics of grafted cucumbers, including their susceptibility to plant diseases. Hasama et al. stated that these rootstocks caused increased powdery mildew damage (Podosphaera xanthii (Castagne) U. Braun and N. Shishkoff) and Corynespora leaf spot (Corynespora cassicola (Berk. and M. A. Curtis) C. T. Wei) on cucumber scions [16]. In contrast, Morishita et al. observed the suppression of powdery mildew growth on the leaves of a susceptible cultivar grafted onto a resistant wild-type cucumber. These results suggested that the rootstock might transmit the resistance of cucumber scions to powdery mildew. There is a demand for new bloomless rootstock cultivars that confer powdery-mildew tolerance or resistance to cucumber scions, although the potential effects of grafting are unclear [17].

In this study, we examine the effects of grafting hybrid cucumber scion onto four local cucurbitaceous rootstocks on plant vegetative growth, plant resistance to powdery mildew disease, fruit yield characteristics, and nutrient concentrations uptake in different organs of the plant. We also evaluate the effects of rootstocks on fruit texture and physical properties under storage using crispness index [18]. 


\section{Material and Methods}

This experimental study was conducted during three consecutive crop seasons of 2017 to 2019 under controlled conditions (Temperature $28{ }^{\circ} \mathrm{C}$ and $90 \%$ humidity) at Floriculture Research Station. The hybrid scion cucumber cv. Kalaam $\mathrm{F}_{1}$ from Syngenta Seed Company was grafted onto four different local cucurbitaceous rootstocks: Ridge gourd (Luffa operculata), Bitter gourd (Momordica charantia), Pumpkin (Cucurbita pepo), and Bottle gourd (Lagrenaria siceraria) under tongue grafting technique, as shown in Table 1.

Table 1. Grafting material and scion/rootstocks combination with their description.

\begin{tabular}{cc}
\hline Grafting Materials & Scion/Rootstock Combination \\
\hline Scion & K/Rid. gourd = Kalam $\mathrm{F}_{1} /$ Ridge gourd \\
Cucumber cv. Kalaam $\mathrm{F}_{1}$ & K/Bit. gourd $=$ Kalam $\mathrm{F}_{1} /$ Bitter gourd \\
Rootstocks & K/Pumpkin $=$ Kalam $\mathrm{F}_{1} /$ Pumpkin \\
Ridge gourd (Luffa Operculata) & K/Bot. gourd $=$ Kalam $\mathrm{F}_{1} /$ Bottle gourd \\
Bitter gourd (Momordica Charantia) & Kalam $\mathrm{F}_{1}=$ Kalam $\mathrm{F}_{1}$ (real rooted) \\
Pumpkin (Cucurbita Moschata) & Replications; R1, R2, R3 \\
Bottle gourd (Lagrenaria Siceraria) & \\
\hline
\end{tabular}

Scion and rootstock nursery was prepared in the first week of August during all three seasons in 200 cell trays $(280 \times 540 \times 40 \mathrm{~mm})$ with peat moss and vermiculate ratio 1:1 $(\mathrm{v} / \mathrm{v})$ as growing media to maintain better air-water composition. After 15 days, the grafting was performed depending upon the diameter of scion and rootstock and the grafts were shifted into disposable plastic pots filled with same growing media. Before the grafting process, plant material and tools were interacted with laminar flow of UV light to kill microbes. Each grafting combination (Table 1) utilized 50 plants of rootstock and scions, respectively, and were replicated three times. After 30-35 days, the grafted plants under uniform growing (temperature and humidity) conditions were transplanted into tunnel having $10 \mathrm{~m}$ length $\times 1.25 \mathrm{~m}$ width plant row and $0.5 \mathrm{~m}$ plant-to-plant distance. The soil characteristics were $\mathrm{pH} 7.3$, electrical conductivity (EC) $0.14 \mathrm{mS} \mathrm{cm}^{-1}, \mathrm{NO}_{3} 15 \mathrm{mg} \mathrm{dm}$, P $4 \mathrm{mg} \cdot \mathrm{dm}^{3}, \mathrm{~K} 31 \mathrm{mg} \mathrm{dm}$, Ca $28 \mathrm{mg} \mathrm{dm}$, $\mathrm{Mg} 17 \mathrm{mg} \mathrm{dm}^{3}$, and total nitrogen $0.25 \%$. Nitrogen $(\mathrm{N})$, phosphate $(\mathrm{P})$, and potassium $(\mathrm{K})$ fertilizer were also used. Before transplanting the crop, the phosphorous was applied. Nitrogen and $\mathrm{K}_{2} \mathrm{O}$ fertilizers were applied into three equal separate dosages. The first dosage was used before transplanting, while the second and third dosages were applied after 20-day intervals. The cucumber fruit harvesting was started after 70 days from grafting and continue with two-day intervals. The experimental design setup, grafting material, scion/rootstock combination, and their replications are shown in Table 1.

\subsection{Plant Morphological Growth}

After 12 days of grafting, the grafted plants survival rate was calculated by counting the survived plants. Five plants from every plot were randomly chosen and vegetative growth parameters such as plant height $(\mathrm{cm})$, total true leaves per plant, diameter of stem $(\mathrm{cm})$, and total branches per plant were noted. Podosphaera xanthii (Castaggne) also known as sphaerotheca fuliginea was used as powdery mildew. The inoculum was prepared and sprayed onto the first, seventh, and fifteenth leaves with conidial suspension $(105 / \mathrm{ml})$ and incubated according to guidelines of Reference [19]. The cotyledon of inoculated selected leave was taken from all four rootstocks cultivars and incubated at $20^{\circ} \mathrm{C}$ to $26{ }^{\circ} \mathrm{C}$ for three tests because the resistive reaction of some cucurbitaceous rootstocks was temperature dependent [19].

The macro (N, P, K, Ca, and $\mathrm{Mg}$ ) and micro $(\mathrm{Fe}, \mathrm{Cu}, \mathrm{Mn}$, and $\mathrm{Zn})$ plant nutrients contents were measured in plant leaf, fruit flesh, fruit rind, and seed. Leaf samples were collected and analyzed at the flowering stage, while fruit flesh, fruit rind, and seed samples were taken at the fully ripening stage of cucumber fruit from different cucurbitaceous and hybrid rootstocks. Kjheldahl method was applied to estimate Nitrogen contents, while Vanado-molybdophosphoric acid method was used to determine 
Phosphorous concentration. The other nutrients concentrations ( $\mathrm{K}, \mathrm{Ca}, \mathrm{Mg}, \mathrm{Fe}, \mathrm{Mn}, \mathrm{Zn}$, and $\mathrm{Cu}$ ) were observed through atomic absorption spectrophotometry technique.

\subsection{Fruit Yield Characteristics}

The number of fruits/plant were determined after harvesting, and 10 fruits from every plot were randomly selected to resolute fruit diameter $(\mathrm{cm})$, fruit length $(\mathrm{cm})$, fruit weight, and shape index per cucumber plant. The fruit shape index was calculated by dividing fruit length with fruit diameter. Total soluble solids (TSS, \%) in fruit juice were measured by using refractometer, and five fruits samples were analyzed from each scion-rootstock combination. Fruit dry mass (\%) was measured by drying $100 \mathrm{~g}$ of fresh fruit weight in an oven at $70^{\circ} \mathrm{C}$ until a constant weight condition.

\subsection{Postharvest Fruit Quality}

The physical properties of fruit texture such as flesh firmness, placental firmness, skin toughness, and crispness index from both local cucurbitaceous and hybrid rootstocks were measured at three different stages of fresh and stored fruits at $10{ }^{\circ} \mathrm{C}$ and $25^{\circ} \mathrm{C}$ for 10 days [20]. For storage, 10 fruits of uniform size were put together, well-insulated with polythene bags $\left(400 \times 290 \mathrm{~mm}^{2}, 0.03 \mathrm{~mm}\right.$ thickness) to maintain humidity level inside the insulation, and stored at $10^{\circ} \mathrm{C}$ and $25^{\circ} \mathrm{C}$ for 10 days. Transverse slices ( $15 \mathrm{~mm}$ thick) were obtained from the midsection of each selected fruit to measure flesh and placental firmness, while $5 \mathrm{~mm}$ thick samples with skin were also prepared to examine skin toughness. The physical properties of cucumber fruit were measured using a texture profile unit (TPU-2S, Yamaden Co., Tokyo, Japan) with a $3 \mathrm{~mm}$ plunger moving at $150 \mathrm{~mm} \cdot \mathrm{min}^{-1}$. The crispness index was calculated from force-distance curve data for the flesh [21]. The crispness index has no unit, so relative values of crispness indices were determined for comparison in each test. All the readings were taken every $48 \mathrm{~h}$. The weight of each polythene insulated cucumber fruit samples was measured gravimetrically before and after storage, and weight loss percentage of fruit was obtained using Equation (1).

$$
\text { Weight loss }(\%)=\frac{\text { Intial fruit weight }- \text { Final fruit weight }}{\text { Initial fruit weight }} \times 100
$$

\subsection{Economic Analysis}

Essentially, economic feasibility is an important aspect for long-term sustainability assessment of cucumber grafting and production. At present, research interest in vegetable grafting in the world is on rise; however, the high cost of the grafted plant is a major concern for wider adaptation among vegetable growers with large production acreage. Keeping in view adopting prospects of cucumber grafting, the economic analysis is taken into consideration in the first place. The economic analysis of cucumber production was done based on fixed and variable costs. The variable costs included the costs of chemicals, fuel, human labor, nursery, fertilizers, irrigation water, electricity, repair, and maintenance. The fixed costs included general overhead expenses, interest on greenhouse and machinery, land rent, greenhouse and machine tools depreciation value, and machinery housing cost. The following formulae were used in the calculation of gross, absolute, and relative profit indicators.

$$
\begin{aligned}
& \text { Gross return }=\text { Yield }\left(\mathrm{kgha}^{-1}\right) \times \text { Yield price }(\$ / \mathrm{kg}) \\
& \text { Gross profit }=\text { Gross return }- \text { variable costs }(\$ / \mathrm{ha}) \\
& \text { Net profit }=\text { Gross return }- \text { production costs }(\$ / \mathrm{ha}) \\
& \qquad \text { Realtive profit }=\frac{\text { Gross return }}{\text { Production costs }}
\end{aligned}
$$




\subsection{Data Processing and Experimental Design}

The experiment was conducted in a completely randomized design (CRD) to determine whether there is a significant difference in the parameters of scion/rootstock combination. The collected data was analyzed statistically using one-way Analysis of Variance (ANOVA). Tukey's Honest Significant Difference (HSD) at $5 \%$ level of significance was used to assess the significant difference between grafted combination parameters under three replications. The complete statistical analysis was performed using Minitab 17 statistical software (Minitab Pty Ltd., Sydney, Australia).

\section{Results and Discussion}

\subsection{Plant Morphological Growth}

The effect of rootstock cultivates on vegetative growth parameters during three seasons is shown in Figure 1, which indicates the vegetative growth parameters in the real rooted and grafted treatment of hybrid cucumber cv. Kalaam $\mathrm{F}_{1}$ grafted on four local cucurbitaceous rootstocks (ridge gourd, bitter gourd, pumpkin, and bottle gourd). The statistical analysis of experimental data indicated that Cucurbita Moschata (Pumpkin) rootstock had lower plant survival rate during all study seasons as calculated $(68.00 \% \pm 0.58 \%, 74.00 \% \pm 1.00 \%$, and $71.00 \% \pm 0.84 \%)$ in the 1 st, 2 nd, and 3rd seasons, respectively. The results clearly showed the unsuitability or partial incompatibility of local cucurbitaceous pumpkin rootstock with hybrid cucumber scion. The highest significant survival rates $(92.18 \% \pm 0.76 \%, 96.33 \% \pm 0.88 \%$, and $93.00 \% \pm 1.53 \%)$ during all three seasons was noted for hybrid cucumber scion grafted on bottle gourd rootstock (Lagrenaria Siceraria). The survival rate is followed by grafted cucumber on ridge gourd (Luffa Operculata) and bitter gourd (Momordica Charantia) after bottle gourd rootstock in all three seasons, while Kalam $\mathrm{F}_{1}$ gave significant same values with bitter gourd rootstock. These results are comparable and agree with Al-Debei et al. who reported $100 \%$ survival rates when cucumber cultivars grafted onto local resistant rootstocks by tongue or upper grafting method (hole insertion) instead of non-grafted plants [22].

Data of Figure 1 indicated that the grafted plants showed significant increment in plant vigor in all experimental seasons compared to non-grafted (real rooted) of hybrid cucumber. This is displayed in plant height $(\mathrm{cm})$, stem diameter $(\mathrm{cm})$, SPAD value, and branches and leaves per plants. The plant vigor results were significant for ridge, bitter, and bottle gourd rootstocks, while pumpkin rootstock showed nonsignificant improvement in plant growth, similar to real rooted Kalaam $\mathrm{F}_{1}$ hybrid cucumber plants. The leaf chlorophyll content as SPAD value has strong correlation, and the data showed significant differences between grafted and un-grafted cucumber fruits in all seasons while literature study showed nonsignificant difference in chlorophyll content of watermelon on three different rootstocks.

Cultivation of grafted cucumbers in the infested field with nematode showed good vegetative growth as compared to actual rooted plants. This agrees with the findings of Salam et al. in watermelon, reporting that both lengths of vine and the number of lateral branches produced in the grafted plants were higher than un-grafted plants [23]. Differential hormone synthesis (cytokinins, abscisic acid, ethylene, gibberellins, and auxins) controlled by root systems could lead to variations in growth and root to shoot ratios [24]. Sheng Ping et al. stated that the values of plant height, number of leaves, number of branches, and stem diameter were intermediate in cucumber plants grafted on bur cucumber compared with those grafted on pumpkin and self-rooted plants. They concluded that cold resistance and photosynthetic rate as well as yield, fusarium wilt resistance, and root-knot nematode resistance were highest in plants grafted on bur cucumber [25]. The results of this research are also in agreement with research piloted in Turkey; watermelon plants grafted onto bottle gourd rootstocks showed better plant growth performance and produced a higher yield than un-grafted watermelon plants in field contaminated with root-knot nematodes. It was determined that bottle gourd rootstocks can tolerate nematodes with their rapid growth, and at low soil temperature, nematode multiplication is reduced [26]. 

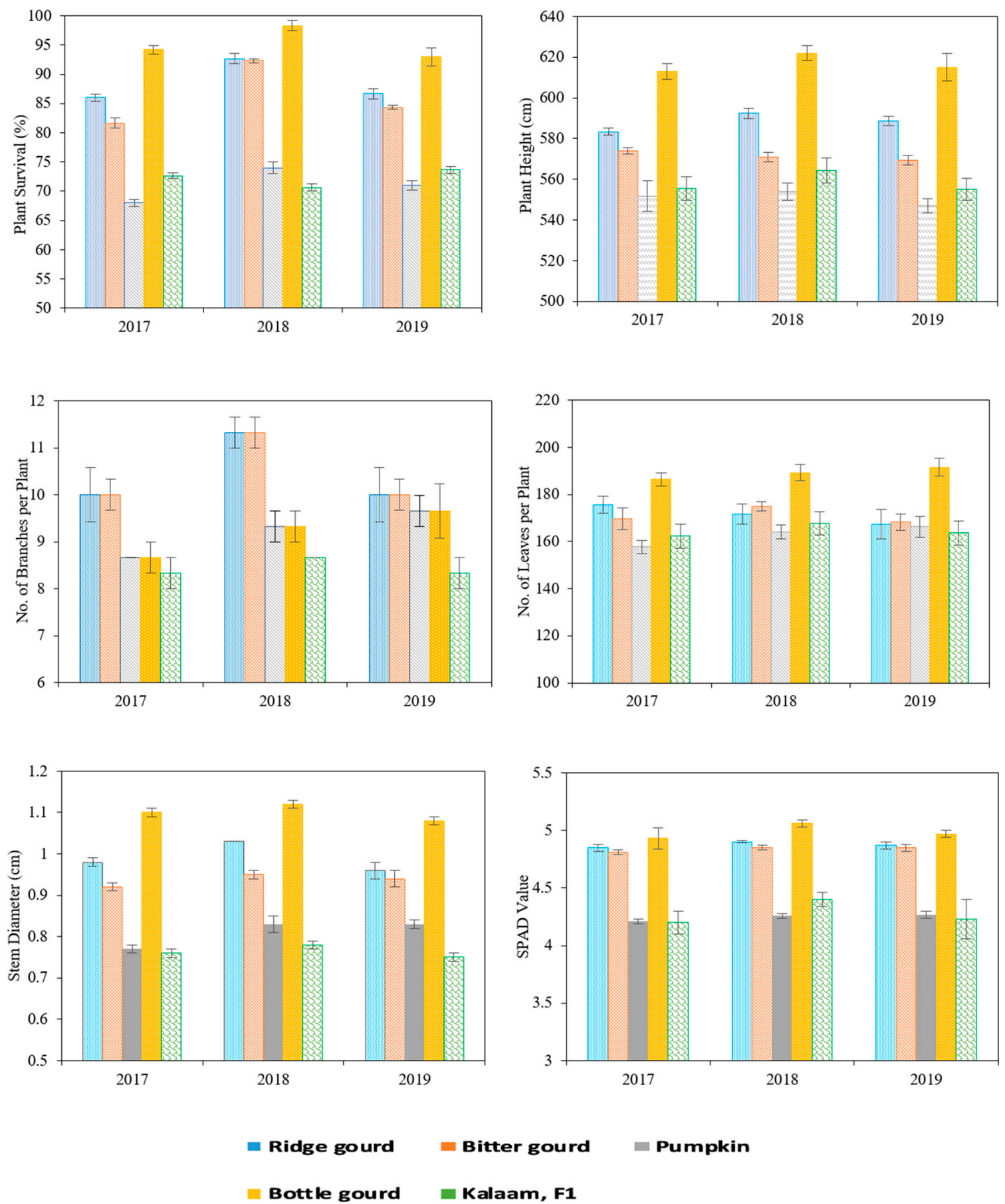

Figure 1. Effect of rootstock cultivars on plant morphological growth characteristics; plant survival (\%); plant height $(\mathrm{cm})$; branches per plant; leaves per plant; stem diameter $(\mathrm{cm})$ and SPAD value.

The powdery-mildew resistances of rootstock cultivars (Table 2) revealed that ridge, bitter, and bottle gourd, tested by detached cotyledons incubated at $20{ }^{\circ} \mathrm{C}$, were most resistant. The symptoms on the leaf surfaces of these cultivars were nearly undetectable because they exhibited very few sporulations under microscope. Pumpkin and Kalaam $\mathrm{F}_{1}$ were resistant at initial growing stage while moderately susceptible to powdery mildew at the seventh true leaf stage. Kalaam $F_{1}$ was found susceptible at the fifteenth true leaf stage during all three seasons, while pumpkin rootstock was found susceptible at the first, seventh, and fifteenth true leaf stages in season 2019. The grafting of pumpkin and Kalaam $\mathrm{F}_{1}$ showed identical and comparable results in all seasons. Generally, the evaluation data 
of resistant rootstock cultivars against powdery mildew showed that local rootstocks with grafting are resistive at initial growth as observed by Reference [27]. These results are consistent with the findings that cucumbers grafted onto rootstocks were less resistant to powdery mildew than grafted onto conventional rootstocks [17]. Conversely, some rootstocks have genetic resistance against nematode. Grafting reduced nematode gall formation in cucumber [27]. In some cases, the rootstocks appear to provide tolerance by providing extensive root area and vigor [27], but some rootstocks have genetic resistance that is exhibited in the grafted plants [28].

Table 2. Evaluation of resistant rootstock cultivars against powdery mildew.

\begin{tabular}{ccccc}
\hline \multirow{2}{*}{$\begin{array}{c}\text { Rootstock Cultivar } \\
\text { (Treatment) }\end{array}$} & Year & \multicolumn{3}{c}{ Disease Index } \\
\cline { 3 - 5 } & & First True Leaf & Seventh True Leaf & 15th True Leaf \\
\hline \multirow{3}{*}{ Ridge gourd } & 2017 & $1.91 \pm 0.20(\mathrm{R})$ & $2.82 \pm 0.20(\mathrm{R})$ & $2.82 \pm 0.40(\mathrm{R})$ \\
& 2018 & $1.25 \pm 0.15(\mathrm{R})$ & $2.75 \pm 0.05(\mathrm{R})$ & $2.15 \pm 0.15(\mathrm{R})$ \\
& 2019 & $2.55 \pm 0.20(\mathrm{R})$ & $2.81 \pm 0.70(\mathrm{R})$ & $2.60 \pm 0.10(\mathrm{R})$ \\
\hline \multirow{3}{*}{ Bitter gourd } & 2017 & $2.72 \pm 0.10(\mathrm{R})$ & $1.85 \pm 0.85(\mathrm{R})$ & $1.84 \pm 0.20(\mathrm{R})$ \\
& 2018 & $2.05 \pm 0.05(\mathrm{R})$ & $2.92 \pm 0.10(\mathrm{M})$ & $2.95 \pm 0.05(\mathrm{M})$ \\
& 2019 & $2.65 \pm 0.35(\mathrm{R})$ & $2.70 \pm 0.20(\mathrm{R})$ & $2.97 \pm 0.10(\mathrm{M})$ \\
\hline \multirow{3}{*}{ Pumpkin } & 2017 & $3.35 \pm 0.20(\mathrm{M})$ & $4.45 \pm 0.95(\mathrm{M})$ & $5.50 \pm 0.30(\mathrm{~S})$ \\
& 2018 & $2.85 \pm 0.15(\mathrm{R})$ & $2.95 \pm 0.35(\mathrm{M})$ & $2.85 \pm 0.35(\mathrm{M})$ \\
& 2019 & $4.75 \pm 0.15(\mathrm{~S})$ & $5.90 \pm 0.10(\mathrm{~S})$ & $7.75 \pm 0.05(\mathrm{~S})$ \\
\hline \multirow{3}{*}{ Bottle gourd } & 2017 & $0.85 \pm 0.85(\mathrm{R})$ & $1.05 \pm 1.05(\mathrm{R})$ & $2.25 \pm 0.25(\mathrm{R})$ \\
& 2018 & $0.55 \pm 0.55(\mathrm{R})$ & $2.45 \pm 0.15(\mathrm{R})$ & $1.22 \pm 0.50(\mathrm{R})$ \\
& 2019 & $1.83 \pm 0.20(\mathrm{R})$ & $2.24 \pm 0.10(\mathrm{R})$ & $2.05 \pm 0.05(\mathrm{R})$ \\
\hline \multirow{2}{*}{ Kalaam, F1 } & 2017 & $2.85 \pm 0.15(\mathrm{R})$ & $4.33 \pm 0.10(\mathrm{M})$ & $5.80 \pm 0.10(\mathrm{~S})$ \\
& 2018 & $2.85 \pm 0.15(\mathrm{R})$ & $5.37 \pm 0.10(\mathrm{~S})$ & $5.87 \pm 0.10(\mathrm{~S})$ \\
& 2019 & $2.85 \pm 0.15(\mathrm{R})$ & $4.32 \pm 0.10(\mathrm{M})$ & $5.83 \pm 0.10(\mathrm{~S})$ \\
\hline
\end{tabular}

Resistance evaluation: $\mathrm{S}=$ susceptible; $\mathrm{M}=$ moderate resistance; $\mathrm{R}=$ resistant. Disease index: $0=$ no symptoms; $9=$ totally and thickly covered with spores and hyphae.

The analysis of macro (N, $\mathrm{P}, \mathrm{K}, \mathrm{Ca}$, and $\mathrm{Mg}$ ) and micro ( $\mathrm{Fe}, \mathrm{Cu}, \mathrm{Mn}$, and $\mathrm{Zn}$ ) plant nutrient in leaf, fruit flesh, rend, and seed is presented in Figure 2. Leaves were sampled at the flowering stage while fruit flesh, rind, and seed were sampled from fully ripe fruits. Rootstocks effects on leaf mineral composition of grafted cucumber was significant. The heights $\mathrm{N}$ concentration of leaf was noted in bottle gourd, while the lowest $\mathrm{N}$ concentration was determined in actual rooted (Kalam $\mathrm{F}_{1}$ ) rootstock. Similar results were observed in $\mathrm{P}$ content. The heights $\mathrm{K}$ content was recorded in ridge gourd leaf; lowest $\mathrm{K}$ content was found in pumpkin and Kalam $\mathrm{F}_{1}$ rootstocks leaves. Bottle had the highest $\mathrm{Ca}$ content, while the lowest $\mathrm{Ca}$ content was in Kalam $\mathrm{F}_{1}$. Pumpkin had more Ca content as compared to Kalam $\mathrm{F}_{1}$. Similar results were found for $\mathrm{Mg}$ content in all leaves. The micronutrients ( $\mathrm{Fe}, \mathrm{Mn}$, and $\mathrm{Cu}$ ) were recorded highest in bottle gourd leaf, and the lowest was observed in real rooted hybrid cucumber rootstocks. The ridge gourd and bottle gourd showed similar $\mathrm{Zn}$ contents.

Fruit rind $\mathrm{N}$ concentration was significantly influenced by both rootstocks and scion. All grafted combinations had a higher content of $\mathrm{N}$ in the rind except for bitter gourd. Hybrid cucumber scion grafted onto bottle gourd had the highest $\mathrm{N}$ concentration, whereas the lowest $\mathrm{N}$ was found in the non-grafted rootstock. Grafting onto bottle gourd rootstocks significantly increased the fruit rind mineral contents, while the rind mineral contents of Kalam $\mathrm{F}_{1}$ were observed as non-significant. Similar results were achieved for micronutrient content of fruit rind except for Fe and Zn. Grafting did not cause any significant increase in Fe concentration of fruit rinds. Ridge gourd and bottle gourd had the heights $\mathrm{Fe}$, while the lowest Fe was determined in bitter gourd. Grafting onto different rootstocks had no significant effect on $\mathrm{Zn}$ content of the fruit rinds. Ridge gourd and pumpkin had the lowest $\mathrm{Zn}$ in the rind, while other combinations had higher $\mathrm{Zn}$ in the rind. 
Mineral composition of the fruit flesh was significantly affected by rootstocks and scion. The fruit flesh harvested from cucurbitaceous rootstocks had higher $\mathrm{N}$ concentration except for bitter gourd/KalamF $F_{1}$ combination. Phosphorous content of fruit flesh showed significant variations based on rootstock and scion. Non-grafted Kalam $F_{1}$ and pumpkin had lower P concentration than others. Grafting increased $\mathrm{K}, \mathrm{Ca}$, and $\mathrm{Mg}$ concentrations of fruit flesh in all grafted combinations significantly while pumpkin/Kalam $\mathrm{F}_{1}$ had lower non-significant values. The lowest Fe concentration was observed in the flesh of pumpkin/Kalam $\mathrm{F}_{1} . \mathrm{Zn}, \mathrm{Mn}$, and $\mathrm{Cu}$ content of the flesh was increased by grafting in all rootstock cultivars, except pumpkin and hybrid rootstocks.

Mineral composition of seed was not affected by rootstocks and scion, except for $\mathrm{Cu}$ and Nitrogen. The highest $\mathrm{N}$ concentration was obtained in the seed among analyzed plant organ in this experiment. Grafting caused significant increase in $\mathrm{N}$ content of the seed in all grafting rootstocks, except for pumpkin with lower $\mathrm{N}$ concentration. Grafting significantly increased seed $\mathrm{Cu}$ content in all rootstock combinations. The lowest seed $\mathrm{Cu}$ concentration was noted in Kalam $\mathrm{F}_{1}$ cultivar.

The nutrients' concentration ranges of analyzed elements were within the standard or normal values reported for cucumber [29], and no deficit symptoms were detected. Current study results revealed the significant effects of both rootstocks and scions on nutrient concentration in leaf. The effect of rootstock/scion on mineral composition of aerial plant parts was principally explained with physical characteristics of the root system, such as lateral and vertical development, which resulted in enhanced uptake of water and minerals, this being one of the main purposes for the widespread use of rootstocks [2]. It was reported that the vigor of rootstock and scion had a significant role in the uptake and translocation of nutrients in grafted fruit [30], while the leaf concentration of certain essential minerals in pistachio plant (Pistachia vera L.) was significantly affected by different rootstocks [31].

In agreement with our results, Ruiz et al. stated that rootstocks/scion combinations were significantly effective on macronutrient concentrations of the grafted melon plants [32]. Micronutrients were significantly affected by cultivar and scion. The amount of micronutrients was higher in grafted cucumber plants than non-grafted plants. The decrease in microelement in grafted plants was explained by the ability of the rootstock to exclude excessive micronutrient. Therefore, the mineral composition of the plants is influenced by the rootstock and scion characteristics, but the impact of the scion and rootstocks may change based on the availability of the element and environmental conditions [33].

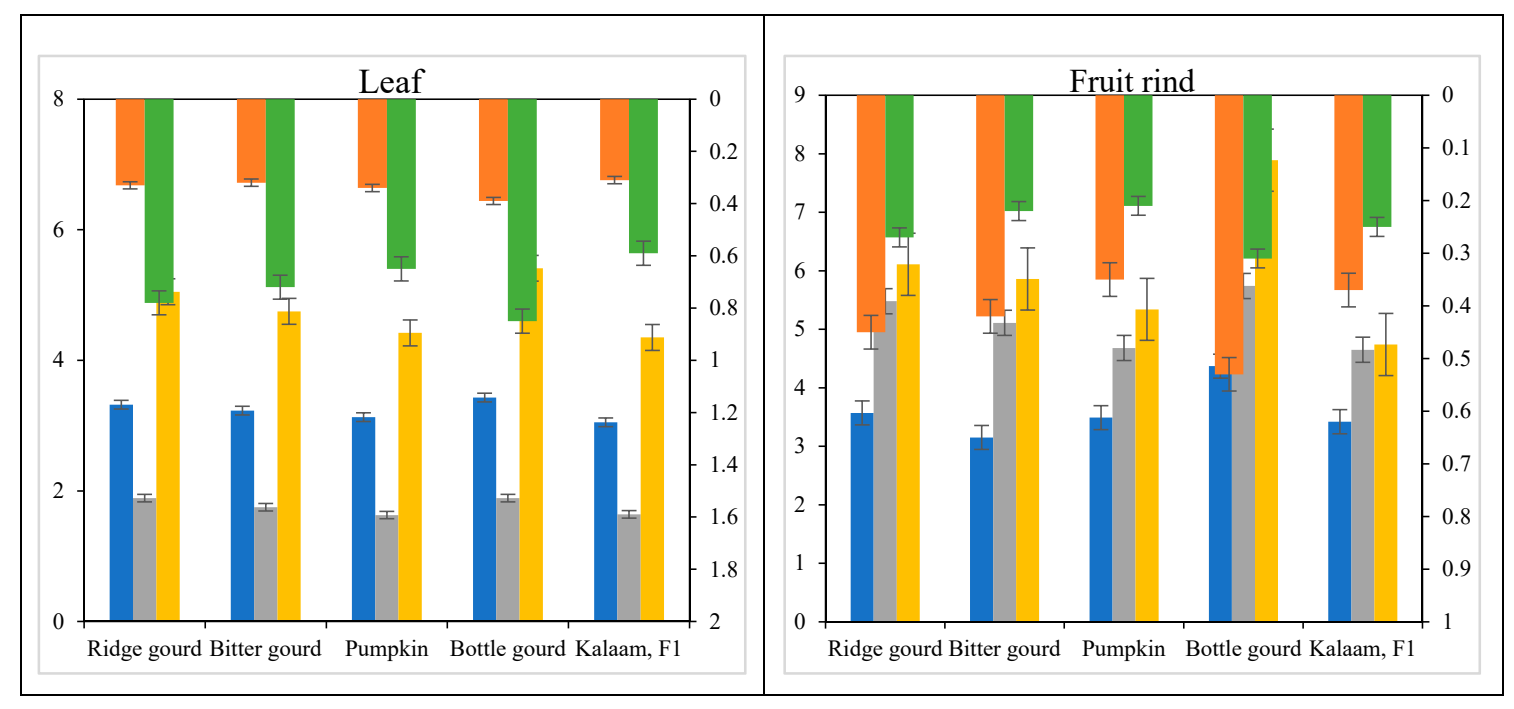

Figure 2. Cont. 


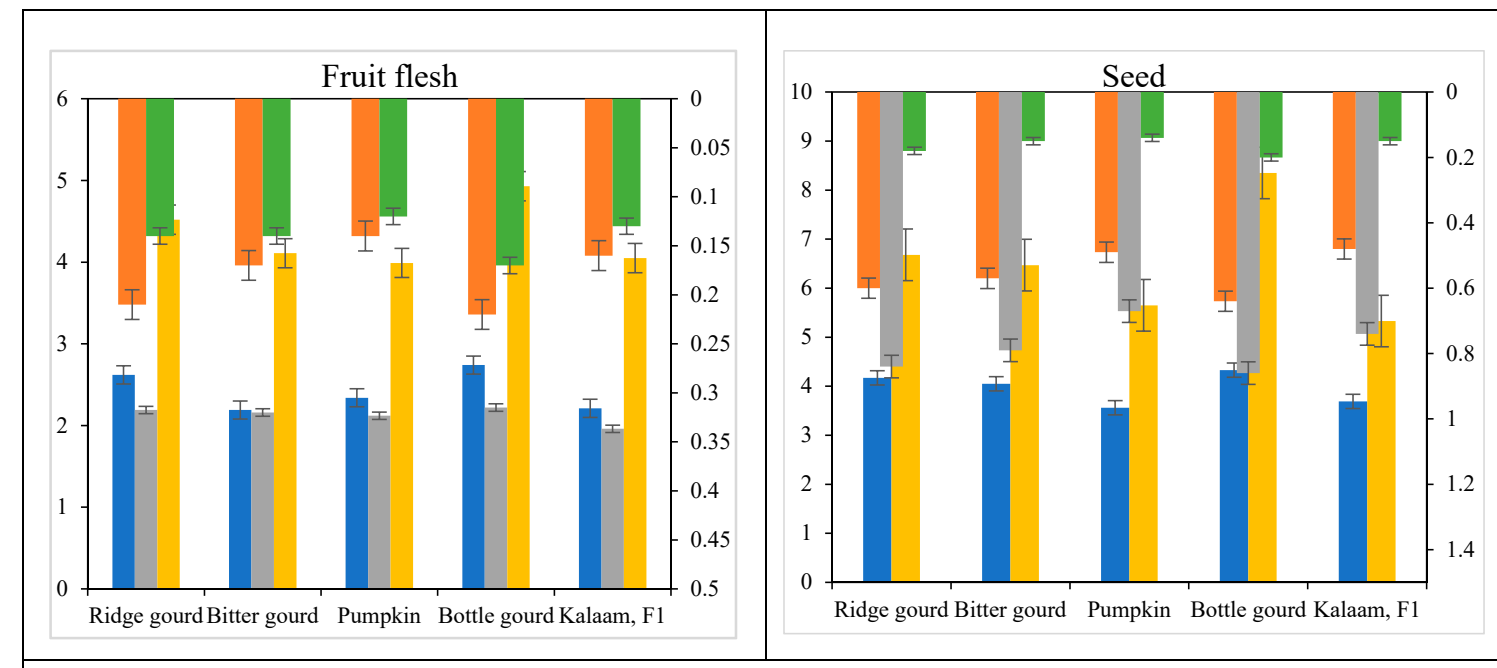

$\square \mathbf{N} \square \mathbf{P} \square \mathrm{K} \backsim \mathrm{Ca} \square \mathbf{M g}$

Macro-nutrient concentration (\%) in leaf, fruit rind, fruit flesh, and seed.

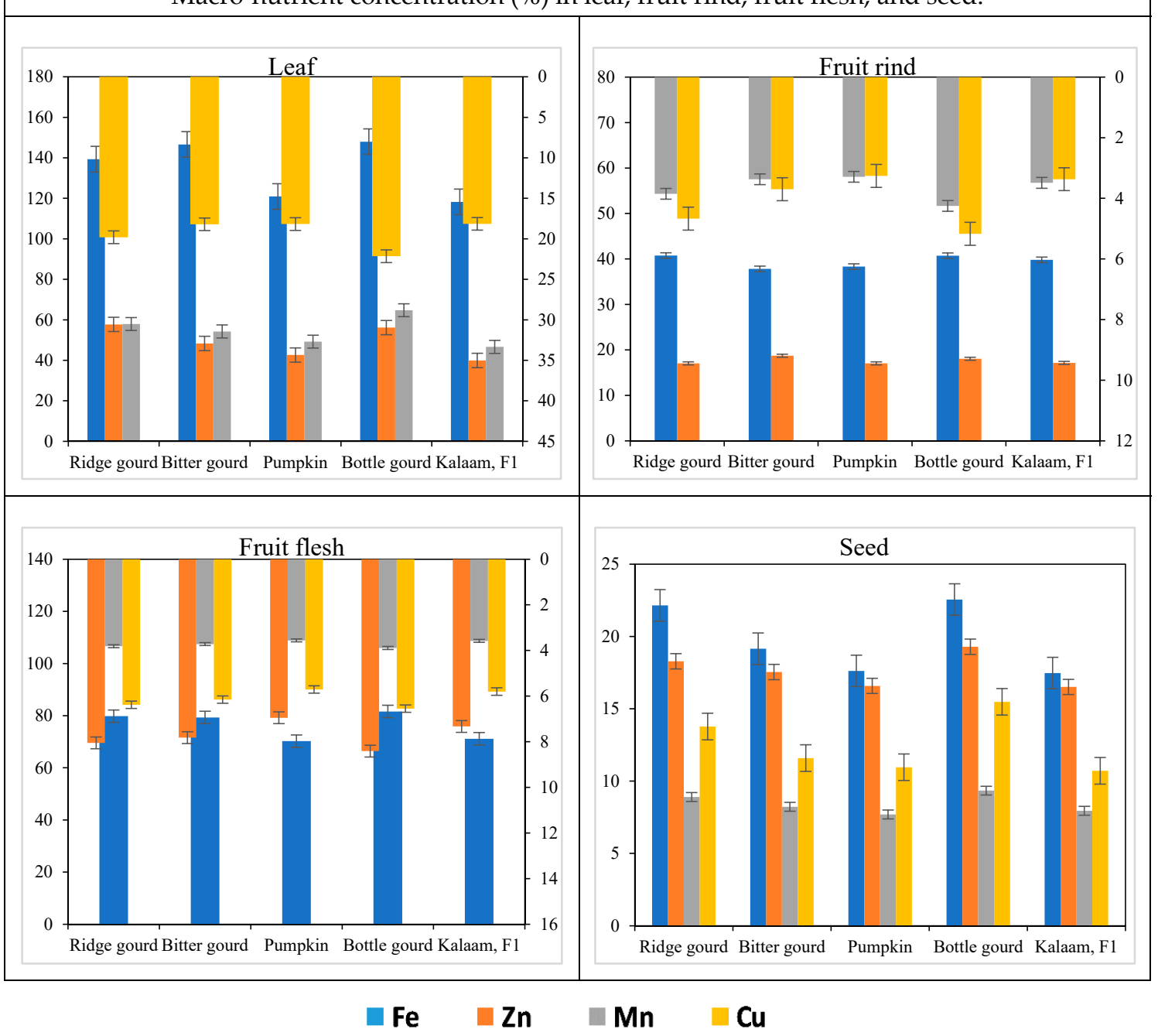

Micro-nutrient concentration (ppm) in leaf, fruit rind, fruit flesh, and seed.

Figure 2. Macro (\%) and micro (ppm) plant nutrient concentration in plant (mean from 2017-2019). 


\subsection{Fruit Yield Characteristics}

Data in Table 3 indicating that, in infested soil with root-knot nematode (Meloidogyne spp), grafting cucumber on all rootstocks had a significant increment in both fresh and dry weights compared with non-grafted hybrid plants in all seasons. The dry matter percentage had a significant decrease when grafting cucumber on Cucurbita moschata (pumpkin) rootstock as compared to non-grafted plants; at the same time, the cucumber plants grafted on hybrid rootstocks (ridge gourd, bottle gourd, and bitter gourd) gave a significant increment in a dry matter as compared to real rooted plants in all seasons. Grafting cucumber on pumpkin rootstocks did not have any significant difference compared with non-grafted cucumber in all three seasons. These results agreed with that of References [34,35]; they disclosed that reduction of cucumber fruit (Cucumis sativus L.) shoot dry weight can be alleviated by grafting onto bottle gourd rootstock. Al-Debei et al. specified that the total dry weight of vegetative parts was $112-123 \%$ higher than non-grafted plants in the first season and $131-152 \%$ in the second season [22].

Table 3 also showed that, in infested soil, grafting cucumbers on Lagernaria rootstocks had the highest values of mean fruit weight, fruit diameters, and fruit length, while the lowest values were recorded for non-grafted followed by grafting of hybrid cucumber on Momordica charantia rootstock in all seasons. Table 3 displayed significant difference between grafted and un-grafted plants in average fruit weight, diameter, length, percent fruit dry matter, and total soluble solids, while fruit shape index between non-grafted hybrid cucumber and pumpkin rootstocks during 2019 season was noted nonsignificant. Bottle gourd grafted cucumber had the highest total soluble solids (TSS) $(5.10 \% \pm 0.01 \%, 5.17 \% \pm 0.03 \%$, and $4.96 \% \pm 0.12 \%)$ in the first, second, and third season, respectively. Similar, results were identified in fruit dry matter percentage by grafting on Lagrenaria rootstocks in all seasons. All other grafted and non-grafted rootstock did not demonstrate any significant change in TSS and dry matter. Cucumbers grafted on all rootstocks under this experiment had considerable fruit dry matter as compared to other local cucurbitaceous and hybrid rootstocks. The use of rootstocks could increase the fruit yield of cucumber [36], though some previous studies proposed that grafting (rootstock) has no significant effect on soluble sugar content and fruit dry matter of cucumber under unstressed conditions [37].

Grafted cucumber plants flowered about 10 days earlier and showed more vigorous vegetative growth than non-grafted (hybrid) plants. Grafted plants had up to $24 \%$ higher fresh weights compared to non-grafted plants. Similarly, grafted plants showed 10-8\% higher dry weight and $13-17 \%$ more leaves as compared to non-grafted plants. Lagrenaria rootstocks produced up to $12-40 \%$ higher yield than control treatment plants in all seasons [7].

The results in Figure 3 and Table 3 showed that there were significant differences between grafted and non-grafted plants yield in terms of weight and number of fruits per plant. The fruit yield was significantly higher in the grafted plants as compared to un-grafted plants. Grafting of hybrid cucumber scion on bottle gourd (Lagrenaria) rootstock gave a significant increment in fruit yield as weight. The number of fruits per plant from grafted cucumber on bottle gourd (Lagrenaria) rootstock showed higher values compared with cucumber grafted on bitter gourd and ridge gourd rootstocks. These results could be due to vegetative growth of Lagrenaria rootstocks, which have higher number of branches and more plant length than all other rootstocks. The increase in total yield from Lagrenaria rootstock was also due to an increase in fruit weight, diameter, and length as a result of grafting on bottle gourd rootstocks. Grafting cucumber on other cucurbitaceous rootstocks also gave significant increment in the yield except for pumpkin rootstock. The lowest yield was obtained for pumpkin (Cucurbita moschata) rootstock grafting. These results agree with that of Al-Debei et al., who found that, when grafting, cucumber cultivar Zezia on (Strongtosa, Shintosa supreme, and Tetsukabuto) by tongue approach or by top grafting (hole-insertion) methods, grafting cucumber on two rootstocks resulted in more vigorous cucumber plants [22]. 
Table 3. Effect of rootstock cultivars on cucumber fruit yield characteristics. TSS: Total soluble solids.

\begin{tabular}{|c|c|c|c|c|c|c|c|c|}
\hline $\begin{array}{l}\text { Rootstock } \\
\text { Cultivar } \\
\text { (Treatment) }\end{array}$ & Year & $\begin{array}{l}\text { Number of } \\
\text { Fruits/Plants }\end{array}$ & $\begin{array}{c}\text { Fruit } \\
\text { Weight/Fruit } \\
\text { (g) }\end{array}$ & $\begin{array}{c}\text { Fruit } \\
\text { Length }(\mathrm{cm})\end{array}$ & $\begin{array}{c}\text { Fruit } \\
\text { Diameter } \\
(\mathrm{cm})\end{array}$ & $\begin{array}{l}\text { Shape } \\
\text { Index }\end{array}$ & TSS (\%) & $\begin{array}{c}\text { Fruit Dry } \\
\text { Matter } \\
(\%)\end{array}$ \\
\hline \multirow{3}{*}{$\begin{array}{l}\text { Ridge } \\
\text { gourd }\end{array}$} & 2017 & $12.86 \pm 0.13$ & $247.52 \pm 2.57$ & $28.51 \pm 0.58$ & $3.51 \pm 0.03$ & $8.12 \pm 0.12$ & $4.88 \pm 0.03$ & $4.34 \pm 0.01$ \\
\hline & 2018 & $13.63 \pm 0.32$ & $257.33 \pm 3.93$ & $30.26 \pm 0.37$ & $3.43 \pm 0.03$ & $8.82 \pm 0.16$ & $4.92 \pm 0.01$ & $4.42 \pm 0.01$ \\
\hline & 2019 & $12.33 \pm 0.33$ & $255.33 \pm 2.33$ & $29.46 \pm 0.75$ & $3.44 \pm 0.03$ & $8.56 \pm 0.24$ & $4.77 \pm 0.03$ & $4.34 \pm 0.03$ \\
\hline \multirow{3}{*}{$\begin{array}{l}\text { Bitter } \\
\text { gourd }\end{array}$} & 2017 & $11.96 \pm 0.33$ & $239.52 \pm 2.84$ & $25.33 \pm 0.33$ & $3.44 \pm 0.03$ & $7.36 \pm 0.18$ & $4.69 \pm 0.01$ & $4.25 \pm 0.03$ \\
\hline & 2018 & $12.53 \pm 0.29$ & $248.66 \pm 2.85$ & $26.16 \pm 0.44$ & $3.53 \pm 0.03$ & $7.41 \pm 0.15$ & $4.72 \pm 0.03$ & $4.45 \pm 0.03$ \\
\hline & 2019 & $11.63 \pm 0.20$ & $246.66 \pm 1.45$ & $23.83 \pm 0.73$ & $3.61 \pm 0.05$ & $6.60 \pm 0.14$ & $4.75 \pm 0.04$ & $4.25 \pm 0.03$ \\
\hline \multirow{3}{*}{ Pumpkin } & 2017 & $9.83 \pm 0.44$ & $218.51 \pm 1.89$ & $20.66 \pm 0.33$ & $3.12 \pm 0.03$ & $6.62 \pm 0.13$ & $4.65 \pm 0.03$ & $3.92 \pm 0.01$ \\
\hline & 2018 & $10.00 \pm 0.40$ & $230.66 \pm 2.03$ & $21.02 \pm 0.58$ & $3.21 \pm 0.03$ & $6.54 \pm 0.19$ & $4.61 \pm 0.03$ & $4.18 \pm 0.04$ \\
\hline & 2019 & $10.33 \pm 0.33$ & $228.33 \pm 0.88$ & $20.44 \pm 0.58$ & $3.26 \pm 0.04$ & $6.27 \pm 0.13$ & $4.57 \pm 0.03$ & $4.00 \pm 0.06$ \\
\hline \multirow{3}{*}{$\begin{array}{l}\text { Bottle } \\
\text { gourd }\end{array}$} & 2017 & $14.03 \pm 0.03$ & $281.66 \pm 0.88$ & $30.13 \pm 0.58$ & $3.88 \pm 0.06$ & $7.77 \pm 0.05$ & $5.10 \pm 0.01$ & $4.55 \pm 0.05$ \\
\hline & 2018 & $15.66 \pm 0.33$ & $280.83 \pm 1.48$ & $31.33 \pm 0.33$ & $3.83 \pm 0.04$ & $8.18 \pm 0.14$ & $5.17 \pm 0.03$ & $4.62 \pm 0.06$ \\
\hline & 2019 & $14.33 \pm 0.33$ & $277.33 \pm 0.88$ & $32.41 \pm 0.33$ & $3.93 \pm 0.03$ & $8.25 \pm 0.04$ & $4.96 \pm 0.12$ & $4.57 \pm 0.22$ \\
\hline \multirow{3}{*}{$\begin{array}{c}\text { Kalaam, } \\
\text { F1 }\end{array}$} & 2017 & $11.1 \pm 0.03$ & $222.51 \pm 1.22$ & $23.11 \pm 0.52$ & $3.11 \pm 0.05$ & $7.43 \pm 0.04$ & $4.61 \pm 0.04$ & $4.10 \pm 0.04$ \\
\hline & 2018 & $10.12 \pm 0.10$ & $231.7 \pm 2.05$ & $22.51 \pm 0.41$ & $3.12 \pm 0.04$ & $7.21 \pm 0.04$ & $4.65 \pm 0.02$ & $4.12 \pm 0.03$ \\
\hline & 2019 & $10.33 \pm 0.05$ & $233.12 \pm 2.62$ & $20.65 \pm 0.71$ & $3.23 \pm 0.05$ & $6.39 \pm 0.04$ & $4.49 \pm 0.03$ & $4.13 \pm 0.02$ \\
\hline
\end{tabular}

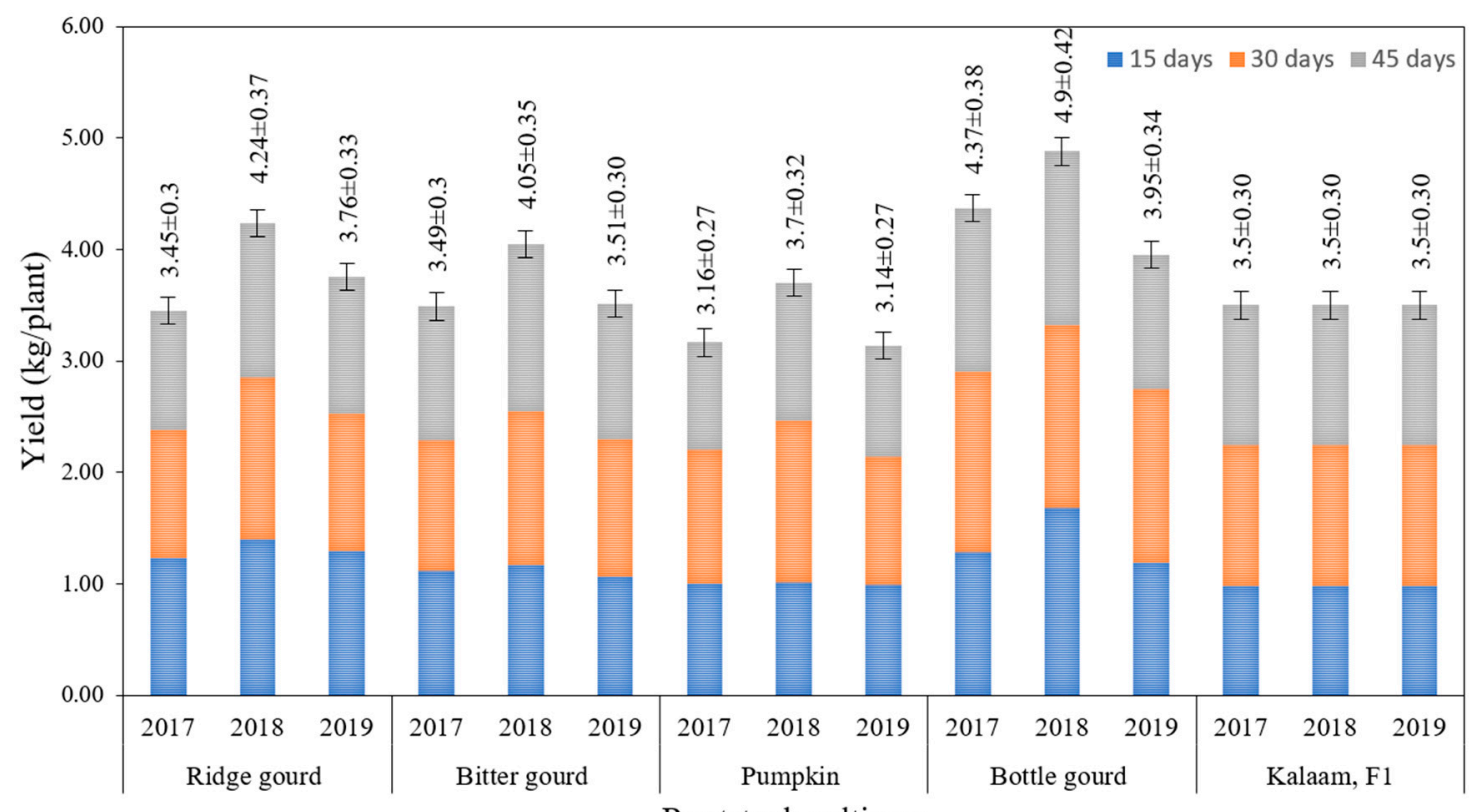

Rootstock cultivars

Figure 3. Yield estimation of different grafted/non-grafted rootstock cultivars.

The effect of rootstocks on the fresh weight, length, and diameter of cucumber fruits is shown in Figure 4. Figure 4A indicated that, after 4 days of pollination, the mean fresh fruit weight increased significantly. The fresh weights of grafted plants were significantly higher than those of non-grafted plants. After 8 days of pollination, grafting increased fruit fresh weight as compared to non-grafted. The length of fruit improved significantly after 3 to 7 days of pollination (Figure 4B). The grafted plants showed significant longer fruit length compared to non-grafted plants after 8 days of pollination. However, fruit diameters increased slowly from first to 4 days after pollination and increased significantly from four to 7 days after pollination. Fruit diameters of grafted plants were significantly higher than non-grafted plants. After 8 days of pollination, fruit diameters of grafted plants exceeded significantly than non-grafted plants as shown in Figure 4C. The analysis concluded that grafted plants showed significantly higher weight, length, and diameter of fresh fruit non-grafting plants. 

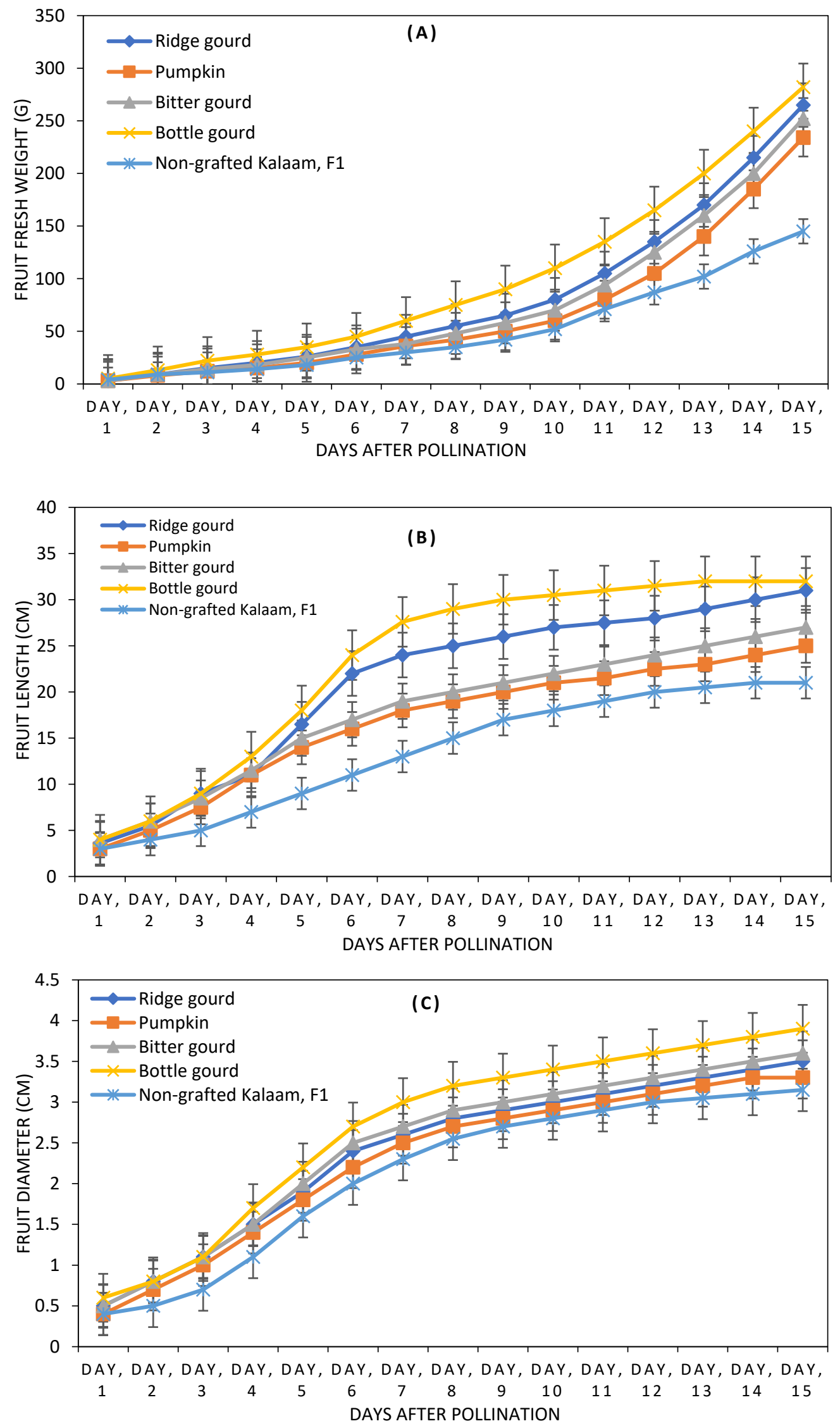

Figure 4. Effects of rootstocks on the fresh weight, length, and diameter of cucumber. 
In general, the yield of grafted or un-grafted plants depends on plant growth characteristics and the results obtained during this study related to plant vegetative growth and yield were comparable and in agreement with previous studies. Cansev and Ozgur reported that, in general, the yield and growth of non-grafted plants were significantly reduced, compared with grafted plants. Similarly, plants development and growth parameters were improved in grafted plants as compared to non-grafted hybrid cucumber [10]. Sheng Ping et al. found that cucumber plants grafted on bur cucumber rootstock (Sicyos angulatus) showed earlier first female flowering and first harvesting date than those grafted on black seed pumpkin rootstock (Cucurbita ficifolia) and self-rooted plants [25]. Higher fruit yield as total fruit weight was obtained in cucumber grafted on squash hybrid Shelper than non-grafted plants [38]. Zhen De et al. stated that grafted cucumber with rootstocks Huangzhen No.3 and Xindongli has better quality, higher yield, and good control of southern root-knot nematode. Root-knot nematodes can cause substantial damage to cucurbits. All cucurbits are susceptible to root-knot nematodes. Damage is typically greatest in warm regions with light, sandy soils. Nematode infested plants may have reduced growth and lower yield and fruit quality and tend to wilt earlier under moisture stress [39]. Meloidogyne spp. can cause yield losses of over 30\% in various vegetable crops [40]. The higher yield was obtained using Shintoza rootstocks compared to non-grafted plants [41].

\subsection{Postharvest Fruit Quality}

The physical properties (flesh firmness, placental firmness, skin toughness, and crispness index) indicate the cucumber fruit texture and the comparison of these properties of freshly harvested cucumber fruits during study seasons is shown in Table 4. The cultivar with the firmest flesh and placenta was bottle gourd followed by bitter gourd, ridge gourd, Kalam $\mathrm{F}_{1}$, and pumpkin. Bottle gourd and ridge gourd cultivars had the toughest skin, followed by Kalam $F_{1}$ and bitter gourd. Pumpkin cultivars had softer flesh and placenta and more tender skin. Generally, nonsignificant effect of rootstock cultivars was detected on flesh and placenta firmness and skin toughness, while greatest variability among cultivars was observed for the crispness index. The highest crispness indices were observed for bottle gourd $(113.5 \% \pm 0.95 \%)$ rootstock during 2018 season, while the lowest crispness index $(86.2 \% \pm 3.00 \%)$ was noticed for ridge gourd rootstock during 2017 season.

Table 4. Effect of rootstock cultivars on the fruit physical properties.

\begin{tabular}{cccccc}
\hline $\begin{array}{c}\text { Rootstock } \\
\text { Cultivar } \\
\text { (Treatment) }\end{array}$ & Year & $\begin{array}{c}\text { Flesh } \\
\text { Firmness (N) }\end{array}$ & $\begin{array}{c}\text { Crispness } \\
\text { Index (\%) }\end{array}$ & $\begin{array}{c}\text { Placental } \\
\text { Firmness (N) }\end{array}$ & $\begin{array}{c}\text { Skin } \\
\text { Toughness (N) }\end{array}$ \\
\hline Ridge gourd & 2017 & $10.3 \pm 0.03$ & $86.2 \pm 3.00$ & $3.1 \pm 0.06$ & $10.2 \pm 0.06$ \\
& 2018 & $10.5 \pm 0.03$ & $106.2 \pm 0.72$ & $3.4 \pm 0.03$ & $9.8 \pm 0.03$ \\
& 2019 & $10.4 \pm 0.06$ & $98.9 \pm 1.10$ & $3.3 \pm 0.03$ & $10.0 \pm 0.03$ \\
\hline \multirow{3}{*}{ Bitter gourd } & 2018 & $10.2 \pm 0.03$ & $93.4 \pm 1.79$ & $3.2 \pm 0.02$ & $10.0 \pm 0.03$ \\
& 2019 & $10.2 \pm 0.00$ & $105.5 \pm 0.87$ & $3.1 \pm 0.03$ & $9.8 \pm 0.03$ \\
\hline \multirow{3}{*}{ Pumpkin } & 2017 & $10.1 \pm 0.03$ & $88.3 \pm 2.51$ & $3.1 \pm 0.06$ & $9.8 \pm 0.03$ \\
& 2018 & $10.1 \pm 0.03$ & $101.4 \pm 0.46$ & $3.3 \pm 0.03$ & $9.9 \pm 0.03$ \\
Bottle gourd & 2019 & $10.3 \pm 0.03$ & $111.9 \pm 0.06$ & $3.0 \pm 0.03$ & $9.7 \pm 0.06$ \\
\hline \multirow{2}{*}{ Kalaam, F1 } & 2017 & $10.4 \pm 0.06$ & $95.9 \pm 3.15$ & $3.3 \pm 0.00$ & $9.9 \pm 0.06$ \\
& 2019 & $10.4 \pm 0.03$ & $113.5 \pm 0.95$ & $3.8 \pm 0.03$ & $10.0 \pm 0.06$ \\
& 2017 & $10.1 \pm 0.03$ & $100.0 \pm 0.02$ & $3.2 \pm 0.03$ & $10.1 \pm 0.03$ \\
& 2019 & $10.4 \pm 0.03$ & $100.0 \pm 0.32$ & $3.8 \pm 0.03$ & $9.9 \pm 0.09$ \\
& $10.3 \pm 0.03$ & $100.0 \pm 1.65$ & $3.3 \pm 0.03$ & $10.1 \pm 0.03$ \\
\hline
\end{tabular}

Two-storage test, one at $10{ }^{\circ} \mathrm{C}$ and the other at $25^{\circ} \mathrm{C}$, was performed to evaluate the influence of storage on physical properties of fruits as shown in Figure 5. For the $10^{\circ} \mathrm{C}$ storage test, it was observed 
that the weight loss is less than $1 \%$, as shown in Figure 6 . Chilling injury commonly caused by cold storage was not observed. Distinct effects of storage at $10{ }^{\circ} \mathrm{C}$ under humid conditions on the physical properties of flesh firmness and the crispness index were observed in all grafted and non-grafted cucumber fruits. The data of bottle gourd cucumber fruits stored at $10{ }^{\circ} \mathrm{C}$ are presented in Figure 5 . Flesh firmness of bottle gourd grafted fruit increased with the storage period until 6 days. Crispness index values also increased with the period of storage, becoming approximately $50 \%$ higher at 10 days. There was also an increasing trend placental firmness and skin toughness with storage until 4 and 8 days accordingly. The data displayed that the fruit skin, flesh, and placenta became firmer/tougher when stored at $10{ }^{\circ} \mathrm{C}$ for 6 days. After 6 days of storage, a slight decline in placental firmness, flesh firmness, and crispness index were observed.

For the $25^{\circ} \mathrm{C}$ storage test, the weight loss during storage at $25^{\circ} \mathrm{C}$ was more than $1 \%$ (Figure 6). Similar to the $10^{\circ} \mathrm{C}$ storage treatment, distinct influences of storage at $25^{\circ} \mathrm{C}$ under humid conditions on the physical properties were clearly observed. Crispness index and flesh firmness values increased with storage period at $25^{\circ} \mathrm{C}$, although the values of after 6 days were not so different. Skin toughness also increased with storage period. The tendency of increasing placental firmness was found on 4 days of storage.

The influence of rootstock cultivars on cucumber fruit texture was also clarified. No distinct influence of the rootstock cultivar on the physical properties of fresh fruits was observed under the experimental conditions in each season. There was also no clear difference between own-rooted cucumber fruits and all grafted cucumber fruits. Furthermore, nearly the same results were observed under humid storage at $10{ }^{\circ} \mathrm{C}$ and $25^{\circ} \mathrm{C}$ for 10 days. These results contradict reports that grafted cucumber fruits have a less desirable texture than non-grafted cucumber fruits [42]. However, there was no obvious difference in flesh firmness and fruit skin toughness in our tests or in previous experiments [43]. It is difficult to clearly explain the inconsistency regarding the texture of grafted cucumbers. However, it may be partially explained by the combination of rootstock and scion cultivars used. Morishita reported that the flesh of "Kema" (local variety) or "Kifujin New type" (Saitama Gensyu Ikuseikai Co., Saitama, Japan) cucumbers grafted onto the bloomless rootstock cultivar of "Big Ben Kitora" (Nanto Seed) became softer than the flesh of own-rooted and ST-grafted cucumbers. On the other hand, his data also showed that there was no firmness difference between "Encore" (Tokiwa Kenkyujo) fruits from ST-grafted plants and those from bloomless rootstock "Big Ben Kitora"-grafted plants [42].

This research study intended to clarify whether grafted cucumber fruits have a less desirable texture real rooted cucumber fruit. In the current experimental study, we could not identify an obvious decline in texture of grafted cucumber fruits. Due to the limitation of samples, we were unable to analyze stored fruits without maintaining the humidity, which is the general condition during transportation of cucumber fruits from producing area to urban market. We also need to conduct sensory evaluation to conclude this issue. As for fresh fruits or fruits stored for several days in humid conditions, we suggest that the influence of rootstocks on physical properties is quite limited and that there is no evidence for a less desirable texture grafted cucumber fruits.

New evidence on texture of cucumber fruits were shown in storage test. Storage in polyethylene bags to maintain the humidity at $10^{\circ} \mathrm{C}$ or $25^{\circ} \mathrm{C}$ for 4 to 10 days resulted in crisper and firmer flesh. The mechanism of this fruit firming is unclear, but it may be caused by physiological changes such as alterations in water distribution at the tissue or cell level rather than biochemical or anatomical changes because the fruit firming occurs within a short period without visible change or weight loss. It was interesting that the differences in physical properties between lower temperature $\left(10^{\circ} \mathrm{C}\right)$ and higher temperature $\left(25^{\circ} \mathrm{C}\right)$ storage in each rootstock were smaller than expected. In previous experiments conducted without maintaining high humidity levels, the firmness of cucumber fruits decreased as the storage period progressed [44]. In general, the stored fruits are not palatable. The main reasons for the loss of palatability are the reduction of components such as fructose and glutamine [45]. The stored cucumber fruits under our condition were not palatable either. They also lost sugars (glucose and 
fructose) with the storage period [14]. In addition, the undesirable texture of fruits was obtained because such fruits are less juicy even firm and crisp.
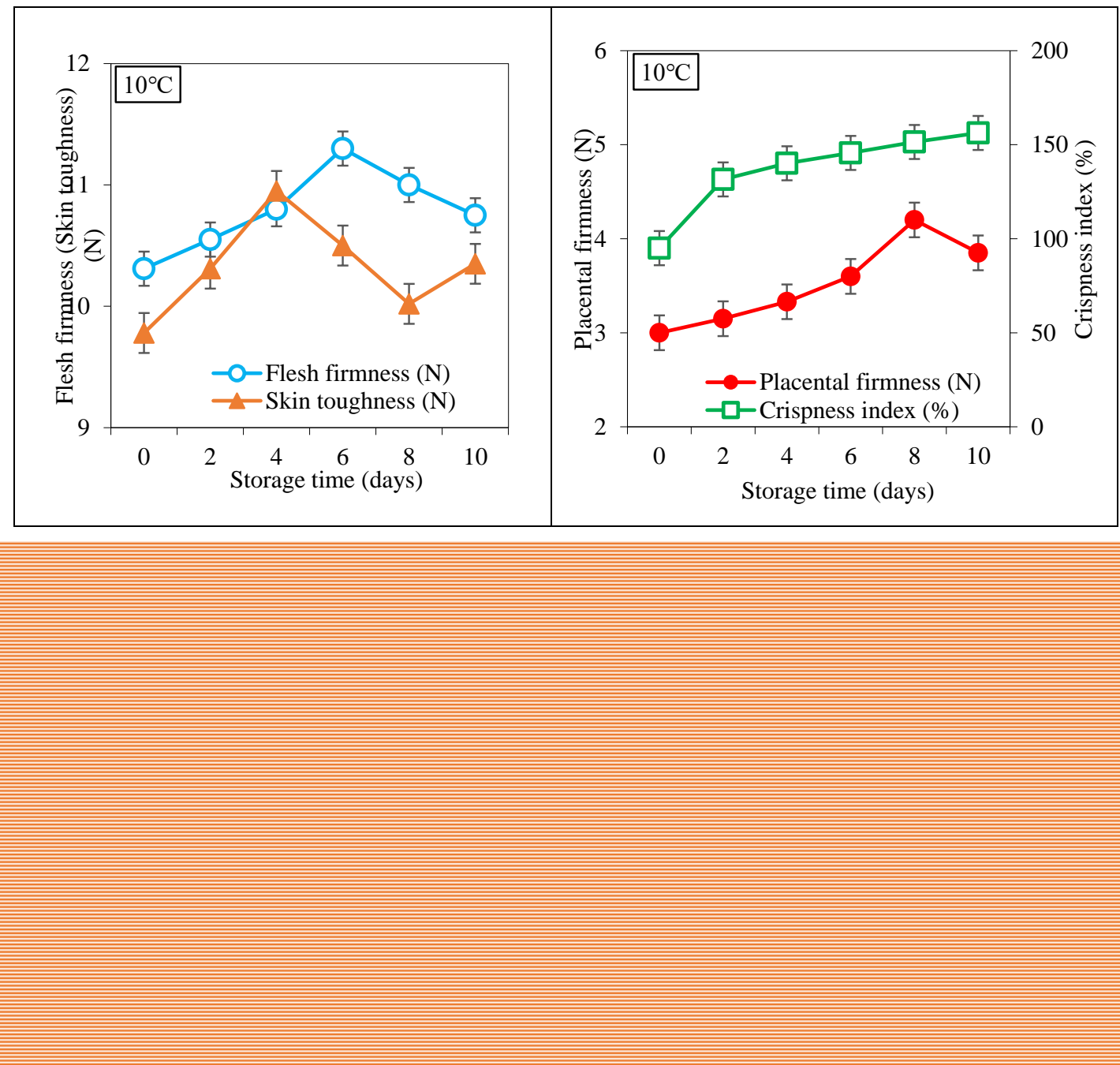

Figure 5. Effects of the storage period on the physical properties of bottle gourd cucumber fruits stored at $10^{\circ} \mathrm{C}$ and $25^{\circ} \mathrm{C}$ : Vertical bars indicate SE $(n=10)$.

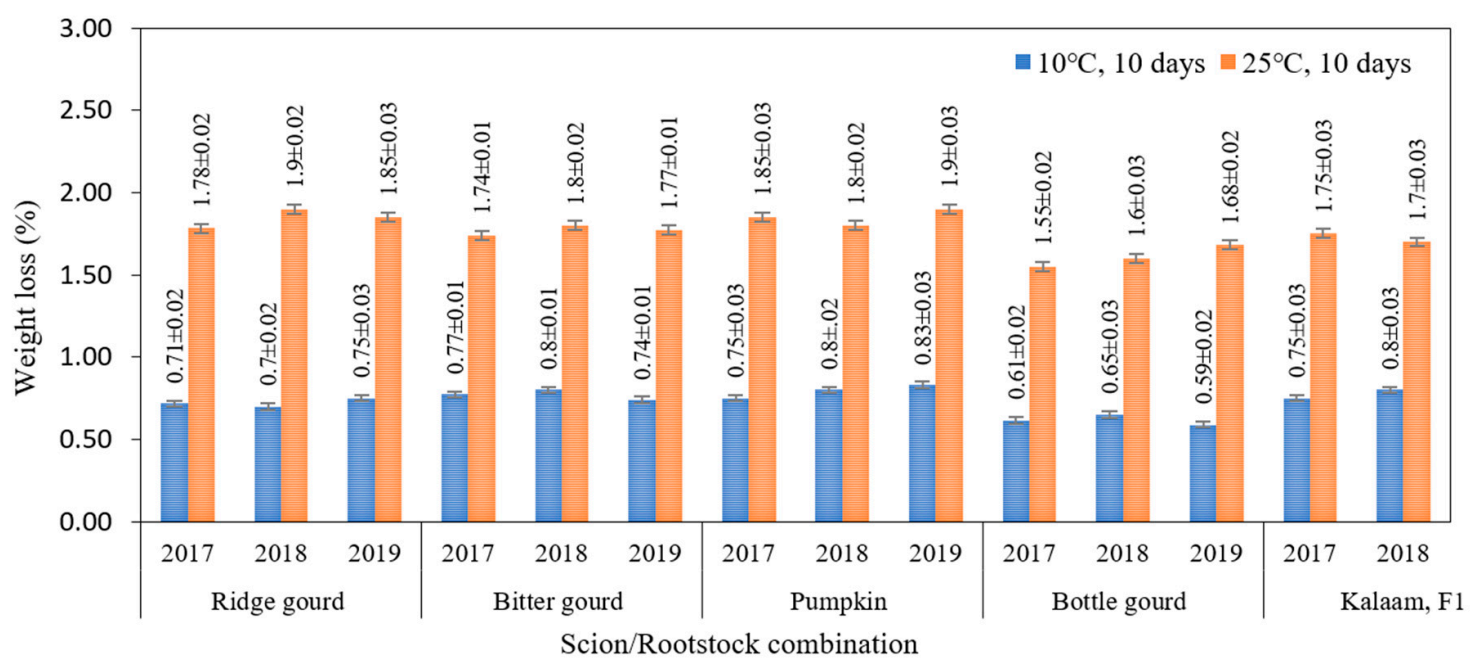

Figure 6. Effect of storage conditions on fruit weight loss of grafted/hybrid plants after storage. 


\subsection{Economic Analysis}

The cost items used in the economic analysis for hybrid and real-rooted cucumber production are shown in Table 5. The total cost per hectare was calculated as $\$ 4763.68$ and $\$ 4713.00$ for the hybrid and grafted cucumber production, respectively. The ratio of total variable cost to total fixed cost was measured as 1.13 and 1.11 in two different production systems, respectively, which indicated more than half of production cost was constituted by the variable cost. Several studies were reported that the ratio of variable costs was higher than fixed costs in cropping systems [46-49]. Moreover, the higher construction cost of greenhouse was the main reason for high production costs.

The gross return (output) value of the production was calculated by multiplying the cucumber yield and cucumber prices. The gross return values were calculated as $\$ 29,641.5$ and $\$ 39,192.5$ per hectare for the hybrid and grafted cucumber production systems, respectively. The gross profit value was found by subtracting the variable costs from the gross return value, and it was calculated as $\$ 27,110.83$ and $\$ 36,712.50$ per hectare for both production systems, respectively. In order to obtain net income in an enterprise, the gross profit value should be higher than the fixed cost. According to the results, the gross output values were determined higher than fixed costs in both cucumber crops.

The net profit value was found by subtracting the production costs from the gross return value and it was calculated as $\$ 24,877.83$ and $\$ 34,479.50 \mathrm{ha}^{-1}$ for the hybrid and grafted cucumber, respectively as shown in Table 6. Based on these results, the relative profit values of greenhouse cucumber production were determined as 6.22 and 8.32, respectively (Table 6). According to economic analysis results, cucumber farming in plastic-covered greenhouses in the study region appeared to be a profitable agricultural activity. Some previous studies determined the profitability of greenhouse cucumber such as the relative profit was calculated as 1.68 [50], 1.79 [49], and 2.70 [48] for greenhouse cucumber.

Table 5. Production cost items and economic analysis of greenhouse cucumber production.

\begin{tabular}{|c|c|c|}
\hline Cost Items (\$ ha $\left.\mathbf{~}^{-1}\right)$ & Hybrid (Non-Grafted) & Grafted \\
\hline Human labor & 1200 & 1237 \\
\hline Diesel \& lubrication & 82.50 & 81.00 \\
\hline Nursery & 215 & 237 \\
\hline Fertilizer and Pesticides & 400 & 300 \\
\hline Water and Electricity & 247.8 & 240 \\
\hline Farmyard manure & 300 & 300 \\
\hline Repair maintenance costs & 85 & 85 \\
\hline Total variable costs $\left(\$ \mathrm{ha}^{-1}\right)$ & 2530.68 & 2480.00 \\
\hline Greenhouse depreciation & 351 & 351 \\
\hline Machinery depreciation & 76 & 76 \\
\hline Interest on greenhouse & 510 & 510 \\
\hline Interest on machinery & 204 & 204 \\
\hline Land rent & 833 & 833 \\
\hline Machinery housing & 69 & 69 \\
\hline General overhead costs & 190 & 190 \\
\hline Total fixed costs $\left(\$ \mathrm{ha}^{-1}\right)$ & 2233 & 2233 \\
\hline Total production costs $\left(\$ \mathrm{ha}^{-1}\right)$ & 4763.68 & 4713.00 \\
\hline Total return $\left(\$ \mathrm{ha}^{-1}\right)$ & $29,641.50$ & $39,192.50$ \\
\hline Net return $\left(\$ h^{-1}\right)$ & $24,877.83$ & $34,479.50$ \\
\hline Benefit/Cost ratio (BCR) & 6.22 & 8.32 \\
\hline
\end{tabular}

Table 6. Calculation of gross, absolute, and relative profit indicators.

\begin{tabular}{ccc}
\hline Profits & Hybrid (Non-Grafted) & Grafted \\
\hline Gross profit $\left(\$ \mathrm{ha}^{-1}\right)$ & $27,110.83$ & $36,712.50$ \\
Net profit $\left(\$ \mathrm{ha}^{-1}\right)$ & $24,877.83$ & $34,479.50$ \\
Relative profit & 6.22 & 8.32 \\
\hline
\end{tabular}




\section{Conclusions}

Grafting is an important integrated pest-management strategy to manage soil-borne pathogens and other pests of cucurbitaceous crops. This research study analyzed that root-knot nematode is the major constrain for plant survival and growth, fruit development and quality, and cucumber production yield. All these factors majorly depend upon scion-rootstock cultivar combination and suitable growing environment. The hybrid cucumber was susceptible to soil nematodes and showed less plant growth and poor nutritional contents and yield. This study evaluates the grafting performance of hybrid scion on local resistant cucurbitaceous rootstocks during 2017-2019 cropping seasons in terms of plant morphometric, fruit yield, and fruit postharvest textural characteristics. The experimental results indicated that, except pumpkin, all other rootstocks showed high compatibility with hybrid cucumber scion and had a significant effect on vegetative growth, yield, and storage performance compared with hybrid rootstock in all seasons. The plants with bottle gourd (Lagrenaria siceraria) rootstock produced significantly higher yield, macro- $(\mathrm{N}, \mathrm{P}, \mathrm{K}, \mathrm{Ca}$, and $\mathrm{Mg}$ ) micronutrients ( $\mathrm{Fe}, \mathrm{Cu}, \mathrm{Mn}$, and $\mathrm{Zn}$ ), and textural properties of cucumber under storage conditions than all other cucurbitaceous and hybrid rootstocks in all three seasons. Pumpkin rootstock results were nonsignificant, similar to the hybrid rootstock. The fruit textural properties were significantly better without quality deterioration at $10^{\circ} \mathrm{C}$ for 10-day storage, while the effect of rootstock cultivars was nonsignificant on physical properties of the fruit. This study concluded that the grafting of hybrid cucumber cv. Kalaam $\mathrm{F}_{1}$ on local resistant cucurbitaceous rootstocks grow well in infested soil and significantly enhanced cucumber production. Grafting is an alternative control measure to grow hybrid cucumber onto local resistant rootstocks for better yield and fruit quality. According to economic analysis, grafted cucumber farming in greenhouses appeared to be a profitable agricultural activity.

Author Contributions: Conceptualization, design, and development, R.S.N. and W.A.; data collection, R.S.N. and W.A., and S.U.; formal analysis, R.S.N., W.A., and S.U.; investigation and methodology, R.S.N.; Supervision, H.C.; visualization, R.S.N. and W.A.; writing - original draft, R.S.N., and F.H.; writing review, F.H., and H.C.; write-up editing, F.H., R.S.N., and W.A. writing-review \& editing, M.A. All authors have read and agreed to the published version of the manuscript.

Funding: This research received no external funding.

Acknowledgments: The authors would like to acknowledge to all the services and technical support provided by College of Economics \& Management, Northeast Forestry University, Harbin 150040, China during research work setting, instrumentation, data collection, and write-up compilation.

Conflicts of Interest: The authors declared no conflict of interest.

\section{References}

1. FAO. Statistical Database. 2011. Available online: www.fao.org.com (accessed on 16 August 2011).

2. Lee, J.M. Cultivation of grafted vegetables: Current status, grafting methods, and benefits. HortScience 1994, 29, 235-239. [CrossRef]

3. Hartman, G.L.; Pawlowski, M.L.; Herman, T.K.; Eastburn, D. Organically Grown Soybean Production in the USA: Constraints and Management of Pathogens and Insect Pests. Agronomy 2016, 6, 16. [CrossRef]

4. Diacono, M.; Persiani, A.; Fiore, A.; Montemurro, F.; Canali, S. Agro-Ecology for Potential Adaptation of Horticultural Systems to Climate Change: Agronomic and Energetic Performance Evaluation. Agronomy 2017, 7, 35. [CrossRef]

5. St Amand, P.C.; Wehner, T.C. Crop loss to 14 diseases in cucumber in the North Carolina for 1983 to 1988. Cucurbit Genet. Coop. Rep. 1991, 14, 15-17.

6. Hartmann, H.T.; Kester, D.E.; Davies, F.T.; Geneve, R.L. Principles of grafting and budding. In Plant 89 Propagation. Principles and Practices, 8th ed.; Pearson: London, UK, 2010.

7. Yetisir, H.; Sarı, N. Effect of different rootstock on plant growth, yield and quality of watermelon. Aust. J. Exp. Agric. 2003, 43, 1269-1274. [CrossRef]

8. Colla, G.; Suarez, C.M.C.; Cardarelli, M. Improving nitrogen use efficiency in melon by grafting. HortScience 2010, 45, 559-565. [CrossRef] 
9. Colla, G.; Rouphael, Y.; Rea, E.; Cardarelli, M. Grafting cucumber plants enhance tolerance to sodium chloride and sulfate salinization. Sci. Hortic. 2012, 135, 177-185. [CrossRef]

10. Cansev, A.; Ozgur, M. Grafting cucumber seedlings on Cucurbita spp.: Comparison of different grafting methods, scions and their performance. J. Food Agric. Environ. 2010, 8, 804-809.

11. Moradipour, F.; Dashti, F.; Zahedi, B. The effect of grafting on yield and some vegetative characteristics of two greenhouse cucumber cultivar. Iran. J. Hortic. Sci. 2010, 41, 291-300.

12. Hoyos Echebarría, P. Influence of different rootstocks on the yield and quality of greenhouses grown cucumbers. Acta Hortic. 2001, 559, 139-144. [CrossRef]

13. Lee, J.; Bang, H.; Ham, H. Quality of cucumber fruit as affected by rootstock. Acta Hortic. 1999, 483, 117-124. [CrossRef]

14. Sakata, Y.; Ohara, T.; Sugiyama, M. The history and present state of the grafting of Cucurbitaceous vegetables in Japan. Acta Hortic. 2007, 731, 159-170. [CrossRef]

15. Davis, A.R.; Perkins-Veazie, P.; Hassell, R.; Levi, A.; King, S.R.; Zhang, X. Grafting effects on vegetable quality. HortScience 2008, 43, 1670-1672. [CrossRef]

16. Hasama, W.; Morita, S.; Kato, T. Resistance to Corynespora target leaf spot in cucumber grafted on a bloomless rootstock. Jpn. J. Phytopathol. 1993, 59, 243-248. [CrossRef]

17. Morishita, M.; Sugiyama, K.; Saito, T.; Sakata, Y. Effect on rootstock on incidence of powdery mildew in cucumber. J. Jpn. Soc. Hortic. Sci. 1999, 68, 513.

18. Uysal, N.; Tuzel, Y.; Oztekin, G.B.; Tuzel, I.H. Effects of different rootstocks on greenhouse cucumber production. Acta Hortic. 2012, 927, 281-289. [CrossRef]

19. Association of Official Analytical Chemists. Official Methods of Analysis of the Association of Official Agriculture Chemists, 12th ed.; A.O.A.C: Washington, DC, USA, 1975.

20. Kanno, T.; Kamimura, S. Measuring textural characteristics and varietal differences of skin toughness and flesh firmness in the cucumber fruit. Bull. Veg. Ornam. Crop. Res. Stn. Jpn. 1978, 25-42.

21. Morishita, M.; Sugiyama, K.; Saito, T.; Sakata, Y. An improved evaluation method for screening and selecting powdery mildew resistant cultivars and lines of cucumber (Cucumis sativus L.). J. Jpn. Soc. Hortic. Sci. 2002, 71, 94-100. [CrossRef]

22. Al-Debei, H.S.; Makhadmeh, I.; Abu-Al Ruz, I.; Al-Abdallat, A.M.; Ayad, J.Y.; Al-Amin, N. Influence of different rootstocks on growth and yield of cucumber (Cucumis sativus L.) under the impact of soil-borne pathogens in Jordan. J. Food Agric. Environ. 2012, 10, 343-349.

23. Salam, M.A.; Masum, A.S.M.H.; Chowdhury, S.S.; Dhar, M.; Saddeque, M.A.; Islam, M.R. Growth and yield of watermelon as influenced by grafting. J. Biol. Sci. 2002, 2, 298-299.

24. Zijlstra, S.; Groot, S.P.C.; Jansen, J. Genotypic variation of rootstocks for growth and production in cucumber: Possibilities for improving the root system by plant breeding. Sci. Hortic. 1994, 56, 185-196. [CrossRef]

25. ShengPing, Z.; XingFang, G.; Ye, W. Effect of bur cucumber (Sicyos angulatus L.) as rootstock on growth physiology and stress resistance of cucumber plants. Acta Hortic. Sin. 2006, 33, 1231-1236.

26. Özarslandan, A.; Sögüt, M.A.; Yetisir, H.; Elekcı glu, I.H. Screening of bottle gourds (Lagenaria siceraria (Molina) Standley) genotypes with rootstock potential for watermelon production for resistance against Meloidogyne incognita (Kofoid \& White, 1919) Chitwood and Meloidogyne javanica (Treub, 1885) Chitwood. Turk. Entomol. Derg. 2011, 35, 687-697.

27. Giannakou, I.O.; Karpouzas, D.G. Evaluation of chemical and integrated strategies as alternatives to methyl bromide for the control of root-knot nematodes in Greece. Pest Manag. Sci. 2003, 59, 883-892. [CrossRef] [PubMed]

28. Sigüenza, C.; Schochow, M.; Turini, T.; Ploeg, A. Use of Cucumis metuliferus as a rootstock for melon to manage Meloidogyne incognita. J. Nematol. 2005, 37, 276-280. [PubMed]

29. Bergmann, W. Nutritional Disorders of Plant: Development, Visual and Analytical Diagnosis; Gustav Fischer Verlag: Jena-New York, Germany, 1992.

30. Tagliavani, M.; Bassi, D.; Marangoni, B. Growth and mineral nutrition of pear rootstocks in lime soils. Sci. Hortic. 1993, 54, 13-22. [CrossRef]

31. Brown, P.H.; Zhang, Q.; Ferguson, L. Influence of rootstock on nutrient acquisition by pistachio. J. Plant Nutr. 1994, 17, 1137-1148. [CrossRef] 
32. Ruiz, J.M.; Belakbir, A.; Lopez-Cantarero, I.; Romero, L. Leaf macronutrient content and yield in grafted melon plants: A model to evaluate the influence of rootstocks to genotype. Sci. Hortic. 1997, 71, 227-234. [CrossRef]

33. Carmen Martínez-Ballesta, M.; Alcaraz-Lópeza, C.; Muriesa, B.; Mota-Cadenasa, C.; Carvajal, M. Physiological aspects of rootstock-scion interactions. Sci. Hortic. 2010, 127, 112-118. [CrossRef]

34. Huang, Y.; Bie, Z.; Liu, Z.; Zhen, A.; Wang, W. Protective role of proline against salt stress is partially related to the improvement of water status and peroxidase enzyme activity in cucumber. Soil Sci. Plant Nutr. 2009, 55, 698-704. [CrossRef]

35. Huang, Y.; Bie, Z.; He, S.; Hua, B.; Zhen, A.; Liu, Z. Improving cucumber tolerance to major nutrients induced salinity by grafting onto Cucurbita ficifolia. Environ. Exp. Bot. 2010, 69, 32-38. [CrossRef]

36. Zhu, J.; Bie, Z.; Huang, Y.; Han, X. Effect of grafting on the growth and ion concentrations of cucumber seedlings under $\mathrm{NaCl}$ stress. Soil Sci. Plant Nutr. 2008, 54, 895-902. [CrossRef]

37. Zhong, Y.Q.; Bie, Z.L. Effects of grafting on the growth and quality of cucumber fruits. Acta Hortic. 2007, 761, 341-347. [CrossRef]

38. Salata, A.C.; Bertolini, E.V.; Magro, F.O.; Cardoso, A.; Wilcken, S.R.S. Effect of grafting on cucumber production and reproduction of Meloidogyne javanica and M. incognita. Hortic. Bras. 2012, 30, 590-594. [CrossRef]

39. ZhenDe, C.; PeiSheng, W.; Ying, Z.; YuLing, J.; ZongJun, W.; Ping, L. Effects of rootstock grafting on yield, quality and control of Meloidogyne incognita of cucumber (Cucumis sativus L.). China Veg. 2012, 8, 57-62.

40. Netscher, C.; Sikora, R.A. Nematode parasites of vegetables. In Plant Parasitic Nematodes in Subtropical and Tropical Agriculture; Luc, M., Sikora, R.A., Bridge, J., Eds.; CAB International: Wallingford, UK, 1990.

41. Lee, J.-M.; Oda, M. Grafting of herbaceous vegetable and ornamental crops. Hortic. Rev. 2003, 28, 61-124.

42. Morishita, M. Origin and characteristics of the local cucumber variety 'Kema' in the Osaka district. Bull. Osaka Agric. Res. Ctr. 2001, 37, 27-34.

43. Horie, H.; Ito, H.; Ippoushi, K.; Azuma, K.; Sakata, Y. Which is more palatable, bloomed cucumber or bloomless cucumber? Nippon Shokuhin Kogyo Gakkai 2004, 69.

44. Ozer, M.H.; Akbudak, B.; Uylaser, V.; Tamer, E. The effect of controlled atmosphere storage on pickle production from pickling cucumbers cv. 'Troy'. Eur. Food Res. Technol. 2006, 222, 118-129. [CrossRef]

45. Nakamachi, A.; Yoshikawa, M.; Kasai, M.; Hatae, K. Change and distribution of taste components during the storage of cucumbers. J. Cook. Sci. Jpn. 2002, 35, 234-241.

46. Yelmen, B.; Şahin, H.; Çakir, M. Energy Efficiency and Economic Analysis in Tomato Production: A Case Study of Mersin Province in the Mediterranean Region. Appl. Ecol. Environ. Res. 2019, 17, 7371-7379. [CrossRef]

47. Pellegrini, P.; Fernández, R.J. Crop intensification, land use, and on-farm energy-use efficiency during the worldwide spread of the green revolution. Proc. Natl. Acad. Sci. USA 2018, 115, 2335-2340. [CrossRef] [PubMed]

48. Sami, M.; Reyhani, H. Environmental assessment of cucumber farming using energy and greenhouse gas emission indexes. J. Inst. Integr. Omics Appl. Biotechnol. 2015, 6, 15-21.

49. Taki, M.; Ajabshirchi, Y.; Mobtaker, H.G.; Abdi, R. Energy consumption, input-output relationship and cost analysis for greenhouse productions in Esfahan Province of Iran. J. Exp. Agric. Int. 2012, 2, 485-501. [CrossRef]

50. Mirasi, A.; Samadi, M.; Rabiee, A.H. An analytical method to survey the energy input-output and emissions of greenhouse gases from wheat and tomato farms in Iran. Biol. Forum Int. J. 2015, 7, 52-58.

(C) 2020 by the authors. Licensee MDPI, Basel, Switzerland. This article is an open access article distributed under the terms and conditions of the Creative Commons Attribution (CC BY) license (http://creativecommons.org/licenses/by/4.0/). 